\title{
First record of the torrent frog Hylodes heyeri (Anura, Hylodidae) in Santa Catarina State, South Brazil and acoustic comparison with the cryptic species Hylodes perplicatus (Anura, Hylodidae)
}

\author{
Juliane Petry de Carli Monteiro ${ }^{1}$ \\ Estevão Jasper Comitti ${ }^{2}$ \\ Rodrigo Lingnau ${ }^{3 *}$ \\ ${ }^{1}$ Hori Consultoria Ambiental \\ Rua Cel. Temístocles de Souza Brasil, 311, CEP 82520-210, Curitiba - PR, Brazil \\ ${ }^{2}$ Universidade da Região de Joinville, CEPA Rugendas \\ Estrada Rio Natal, CEP 89280-970, São Bento do Sul - SC, Brazil \\ ${ }^{3}$ Universidade Tecnológica Federal do Paraná, Campus Francisco Beltrão \\ Linha Santa Bárbara, s/n, Caixa Postal 135, CEP 85601-970, Francisco Beltrão - PR, Brazil \\ * Autor para correspondência \\ rodrigolingnau@utfpr.edu.br
}

Submetido em 02/04/2014

Aceito para publicação em 28/08/2014

\section{Resumo}

Primeiro registro da rã-das-corredeiras Hylodes heyeri (Anura, Hylodidae) para o estado de Santa Catarina, sul do Brasil e comparação acústica com a espécie críptica Hylodes perplicatus (Anura, Hylodidae). Realizamos o primeiro registro da rã-das-corredeiras Hylodes heyeri para o estado de Santa Catarina, sul do Brasil, conhecida anteriormente de localidades ao longo da Mata Atlântica somente nos estados de São Paulo e Paraná. Devido à sua semelhança morfológica e por agora poderem ser encontradas em simpatria, nós também efetuamos uma comparação acústica entre os cantos de anúncio de $H$. heyeri e $H$. perplicatus. Há uma maior variação na duração do canto de ambas as espécies, do que consta na literatura, provavelmente relacionada à variação na temperatura do ar. Para distinguir as duas espécies, além das diferenças nas frequências dominantes, um parâmetro temporal que pode ser utilizado é o intervalo entre as notas, porém não a duração do canto devido à influência da temperatura do ar. Essas descobertas reforçam a urgência de mais atividades de campo para o aumento do conhecimento sobre a distribuição geográfica de anuros, sua conservação e chamamos a atenção para a importância de análises acústicas detalhadas para distinguir espécies crípticas.

Palavras-chave: Bioacústica; Canto de anúncio; Distribuição geográfica; Espécies crípticas; Vocalizações

\section{Abstract}

Herein, we report the first record of the torrent frog Hylodes heyeri in Santa Catarina State, South Brazil, previously known from localities along the Atlantic Rainforest in the states of São Paulo and Paraná. We also performed an acoustic comparison between the calls of $H$. heyeri and $H$. perplicatus due to their morphological similarity and because now they could be found in sympatry. There was a greater variation in advertisement call duration for both species, than previously stated in the literature, probably related to variation in air temperature. To distinguish the two species, besides the differences in dominant frequency, a temporal parameter that could be used was the interval between notes, but call duration should not be used due to the influence of air temperature. Our 
findings reinforce the urgency for more field activities to enhance our knowledge of the geographic distribution of anuran amphibians, to promote their conservation, and to call attention to the importance of detailed acoustic analysis to distinguish cryptic species.

Key words: Advertisement call; Bioacoustic; Cryptic species; Geographic distribution; Vocalizations

\section{Introduction}

Torrent frogs of the genus Hylodes Fitzinger, 1826 represent 24 endemic species of Brazil, mainly associated with the Brazilian Atlantic Forest (HADDAD; POMBAL JR., 1995; LAIA; ROCHA, 2012). These frogs are considered rheophilic, wary, and diurnal, calling mainly during the day, yet with some exceptions calling into the first hours of the night (HADDAD et al., 1996; LAIA; ROCHA, 2012; LINGNAU et al., 2013).

Hylodes heyeri Haddad, Pombal \& Bastos (1996) is allocated in the H. lateristrigatus group, along with 17 other species (HADDAD et al., 1996; COSTA et al., 2009). The species was described from Caverna do Diabo, municipality of Eldorado, São Paulo State, Brazil. Later its geographic distribution was extended southward down to the municipality of Guaratuba in Paraná State (LINGNAU, 2004) and northward up to Parque Estadual Turístico do Alto Ribeira, São Paulo State (ARAÚJO et al., 2010).

Another species of the genus, Hylodes perplicatus (Miranda-Ribeiro, 1926), occurs not far from these localities, in Santa Catarina State. Pavan et al. (2001) were the first to mention a morphological similarity between $H$. heyeri and $H$. perplicatus. Due to this morphological similarity, Haddad et al. (2003) provided a redescription of $H$. perplicatus, and in comparing the advertisement calls of the two species, they found that these were clearly two distinct species. Besides differences in advertisement calls, to date, the two species are geographically separated: $H$. heyeri occurs from southern São Paulo State down to southern Paraná State, whereas $H$. perplicatus is restricted to Santa Catarina around the type-locality in Corupá and São Bento do Sul (HADDAD et al., 2003; FROST, 2014).

In this paper, we report the first record of Hylodes heyeri in Santa Catarina State, in localities in sympatry with $H$. perplicatus, which also led us to comment about the variation in advertisement calls of $H$. heyeri and $H$. perplicatus and reinforce the importance of detailed acoustic analysis for species in the genus Hylodes.

\section{Materials and Methods}

Two field expeditions, each lasting two days, were made to the regions of Rio do Júlio ( $26^{\circ} 17^{\prime} 45^{\prime \prime}$, 49 $06^{\prime} 31^{\prime \prime} \mathrm{W}$; altitude of $712 \mathrm{~m}$ ), and of Castelo dos Bugres (2613'34'S, 4903'08'W; altitude of 846 $\mathrm{m})$, both in the mountains of Serra Dona Francisca, municipality of Joinville, Santa Catarina during October and December 2013. A great portion of Serra Dona Francisca is part of a municipal reserve, Área de Proteção Ambiental (APA) da Serra Dona Francisca.

Specimens of $H$. heyeri and $H$. perplicatus were found on the basis of acoustic survey, and their vocalizations were then recorded. Advertisement calls were recorded with a Tascam DR-40 recorder and Rode NTG-2 microphone. Sonograms and oscillograms were made with the software Avisoft-SASLab Light with fast Fourier transformation of 256 points, $50 \%$ overlap, and Hamming window. Dominant frequencies were obtained with Cool Edit 96 with fast Fourier transformation of 1024 points. Call terminology was according to Heyer et al. (1990), as also used by Lingnau et al. (2008; 2013). We also compared our recordings obtained at Serra Dona Francisca to previous recordings of $H$. heyeri from Morretes, Paraná State (LINGNAU; BASTOS, 2007) and of $H$. perplicatus from São Bento do Sul, Santa Catarina State (HADDAD et al., 2003).

Identification was based mainly on acoustic parameters, because as already mentioned by Haddad et al. (2003), an analysis of advertisement calls is crucial to defining the taxonomic position of some amphibians, particularly for Hylodes species. Vouchers were collected with license ICMBIO 26957-1, and they were housed in the herpetological collection at Universidade Tecnológica Federal do Paraná, Campus Francisco 
Beltrão (RLUTF 921 - 923: H. heyeri and RLUTF 1001: $H$. perplicatus). Species identification was confirmed by comparison of vocalization recordings with the literature and morphological comparison with specimens from CFBH (Célio F. B. Haddad collection, Departamento de Zoologia, I.B., Universidade Estadual Paulista, Rio Claro, São Paulo, Brazil) and ZUEC (Museu de História Natural, Universidade Estadual de Campinas, Campinas, São Paulo, Brazil): Hylodes heyeri: CFBH 2466, 2467 , 2468; ZUEC 8238, 8240, 8242, 8243, 8249, 8250, 8253; Hylodes perplicatus: CFBH 3570, 3572-3574.

\section{Results and Discussion}

During field trips, we found five males of $H$. heyeri (Figure 1A) in the region of Rio do Júlio, Serra Dona Francisca. Calling males were found on rocks and branches along the margin of an affluent of Rio do Júlio. We recorded and collected the advertisement calls of three males (RLUTF 921 - SVL $35.06 \mathrm{~mm}$, RLUTF 922 - SVL $36.28 \mathrm{~mm}$ and RLUTF 923 - SVL $35.83 \mathrm{~mm}$ ). This record extends the distribution of $H$. heyeri approximately $50 \mathrm{~km}$ (straight line) from the municipality of Guaratuba, State of Paraná (LINGNAU, 2004), and it is the first record of this species in Santa Catarina State (Figure 2). With this new data, we can consider that $H$. heyeri occurs along the Atlantic Forest, from southern São Paulo State up to northern Santa Catarina.

Around $8 \mathrm{~km}$ (straight line) from Rio do Júlio, in the locality of Castelo dos Bugres, Serra Dona Francisca, we heard three individuals of $H$. perplicatus (Figure 1B). We recorded and collected the advertisement calls of one male (RLUTF 1001 -SVL $43.89 \mathrm{~mm}$ ). The main acoustic parameters of $H$. heyeri and $H$. perplicatus are presented in Table 1.

In comparing the data from Table 1 and Figure 3 with previous call descriptions of $H$. heyeri, we noted that the advertisement calls described here were longer than those reported from the type-locality by Haddad et al. (1996) (0.72 - $1.53 \mathrm{~s}$ at type-locality) and from Morretes by Lingnau and Bastos (2007) (0.69 - $1.86 \mathrm{~s}$ at Morretes). This should be interpreted with caution, because as shown by Lingnau and Bastos (2007), the call duration in $H$. heyeri is strongly correlated with air temperature: at lower temperatures males show longer duration of advertisement calls. Probably due to this strong correlation with air temperature, males at Rio do Júlio (at $19^{\circ} \mathrm{C}$ ) emitted longer advertisement calls as males from Morretes $\left(20-25.2^{\circ} \mathrm{C}\right)$ and Eldorado $\left(21-23^{\circ} \mathrm{C}\right)$. However, temporal parameters such as note duration, interval between notes and, most importantly, spectral parameters such as dominant frequency were similar at the three localities.

FIGURE 1: Males of Hylodes heyeri (A), and H. perplicatus (B). Hylodes heyeri - RLUTF923, from Rio do Júlio, Serra Dona Francisca, municipality of Joinville, Santa Catarina. Hylodes perplicatus (no voucher) from municipality of São Bento do Sul, Santa Catarina.
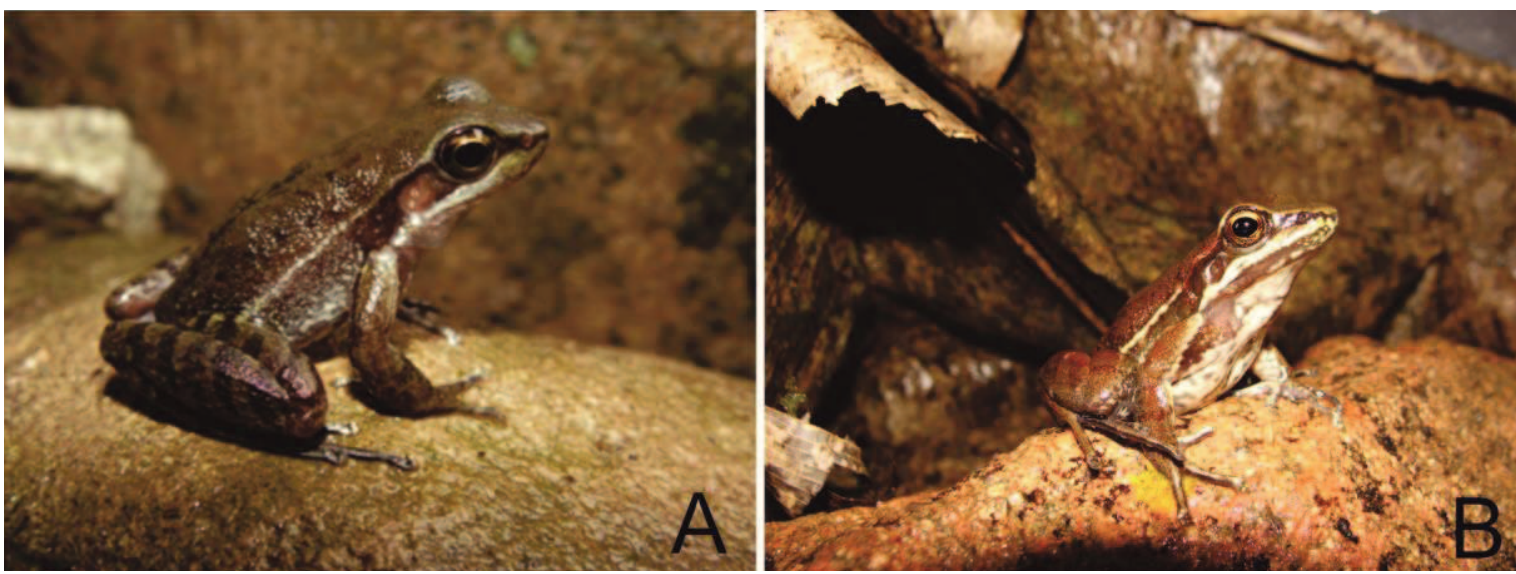
TABLE 1: Acoustic parameters of the advertisement call of Hylodes heyeri and H. perplicatus at Serra Dona Francisca, municipality of Joinville, Santa Catarina, Brazil.

\begin{tabular}{lcccccc}
\hline & \multicolumn{3}{c}{ Hylodes heyeri } & \multicolumn{3}{c}{ Hylodes perplicatus } \\
\hline & Mean \pm SD & $\begin{array}{c}\text { Minimum - } \\
\text { Maximum }\end{array}$ & $\begin{array}{c}\text { Calls / O } \\
\text { recorded }\end{array}$ & Mean \pm SD & $\begin{array}{c}\text { Minimum - } \\
\text { Maximum }\end{array}$ & $\begin{array}{c}\text { Calls / o } \\
\text { recorded }\end{array}$ \\
\hline Call duration (s) & $2.03 \pm 0.34$ & $1.12-2.49$ & $15 / 3$ & $1.01 \pm 0.18$ & $0.75-1.25$ & $5 / 1$ \\
Number of notes per call & $44.93 \pm 7.77$ & $26-56$ & $15 / 3$ & $16.8 \pm 2.58$ & $13-20$ & $5 / 1$ \\
Duration of notes (s) & $0.026 \pm 0.004$ & $0.014-0.034$ & $15 / 3$ & $0.021 \pm 0.004$ & $0.015-0.027$ & $5 / 1$ \\
Interval between notes (s) & $0.024 \pm 0.003$ & $0.018-0.031$ & $15 / 3$ & $0.04 \pm 0.009$ & $0.033-0.057$ & $5 / 1$ \\
Interval between calls (s) & $27.72 \pm 10.17$ & $15.69-54.61$ & $15 / 3$ & $37.89 \pm 11.05$ & $27.6-56.58$ & $5 / 1$ \\
Dominant frequency (kHz) & $4.39 \pm 0.36$ & $3.89-4.89$ & $15 / 3$ & $3.028 \pm 0.1$ & $2.91-3.13$ & $5 / 1$ \\
\hline
\end{tabular}

FIGURE 2: Map of the current geographic distribution of Hylodes heyeri. 1. Eldorado; 2. Morretes; 3. Cananeia; 4. Guaratuba; 5. São José dos Pinhais; 6. PETAR - Parque Estadual Turístico do Alto Ribeira; 7. Guaraqueçaba; 8. Rio do Júlio, Joinville; 9. Castelo dos Bugres, Joinville. Data from: 1. Haddad et al. (1996); 2. Lingnau (2000); 3. Toledo and Lingnau (2002); 4. Lingnau (2004); 5. Conte and Rossa-Feres (2006), Cunha et al. (2010); 6. Araújo et al. (2010) 7. Garey and Hartmann (2012); 8 and 9. Present study.

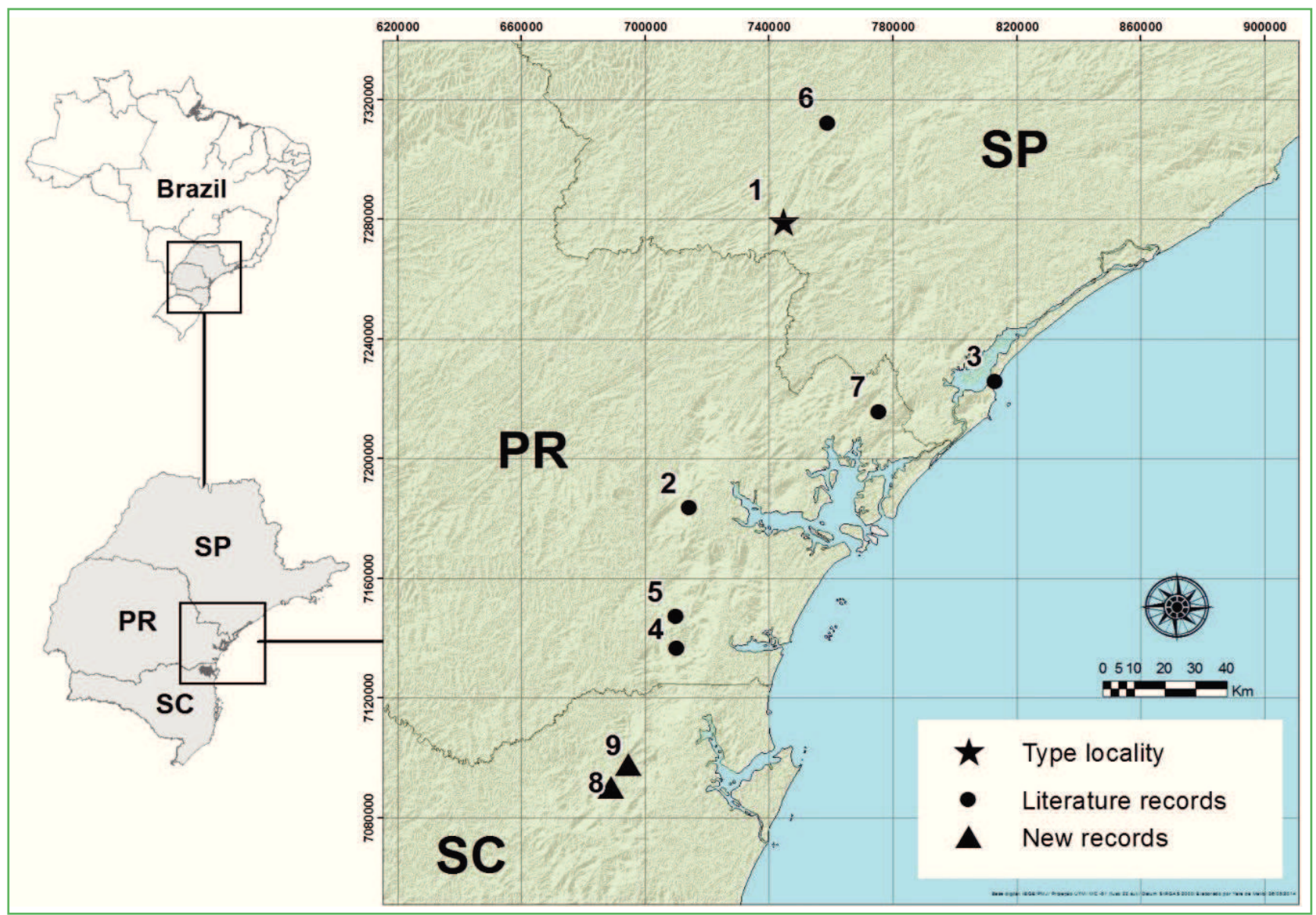


Haddad et al. (2003) compared the advertisement calls of $H$. heyeri and $H$. perplicatus and argued that the advertisement call of $H$. heyeri was shorter than that of $H$. perplicatus based on their recordings. As observed now with our data, this is not always true, because there is a larger variation in call duration in both species, probably related to variation in air temperature. Based only on our recordings from Serra Dona Francisca, we could say that the advertisement call of $H$. heyeri is longer than that of $H$. perplicatus (the opposite of HADDAD et al., 2003), which is demonstrated by the data in Table 1 and Figure 3.

Hylodes heyeri and H. perplicatus are morphologically very similar, yet clearly distinct according to their vocalizations (HADDAD et al., 2003). Besides differences in their dominant frequency, a temporal parameter that could be used to distinguish the two species is the interval between notes, but call duration should not be used due to temperature influence. In $H$. heyeri, the interval between notes of the advertisement call was smaller than in $H$. perplicatus, as already mentioned by Haddad et al. (2003), and we also verified this with our data from recordings of $H$. heyeri and $H$. perplicatus from Serra Dona Francisca, of $H$. heyeri from Morretes (LINGNAU; BASTOS, 2007) and of $H$. perplicatus from São Bento do Sul (HADDAD et al., 2003).

At both localities, Rio do Júlio and Castelo dos Bugres, we found $H$. heyeri and $H$. perplicatus in sympatry. It is very possible that both species could also occur in sympatry along other nearby rivers. Therefore caution is recommended in identifying species of Hylodes, particularly in the region of Serra Dona Francisca, where until recently, all specimens were identified as $H$. perplicatus.

Until now, only three species of Hylodes are recognized in Santa Catarina (H. heyeri, H. meridionalis

FIGURE 3: Advertisement calls of Hylodes heyeri and H. perplicatus from Serra Dona Francisca, municipality of Joinville, Santa Catarina, Brazil. (A) Oscillogram of H. heyeri; (B) oscillogram of H. perplicatus; (C) spectrogram of H. heyeri; and (D) spectrogram of $H$. perplicatus. Hylodes heyeri RLUTF 923 , recorded at $19.0^{\circ} \mathrm{C}$ air temperature; H. perplicatus RLUTF 1001 , recorded at $27.2^{\circ} \mathrm{C}$ air temperature.

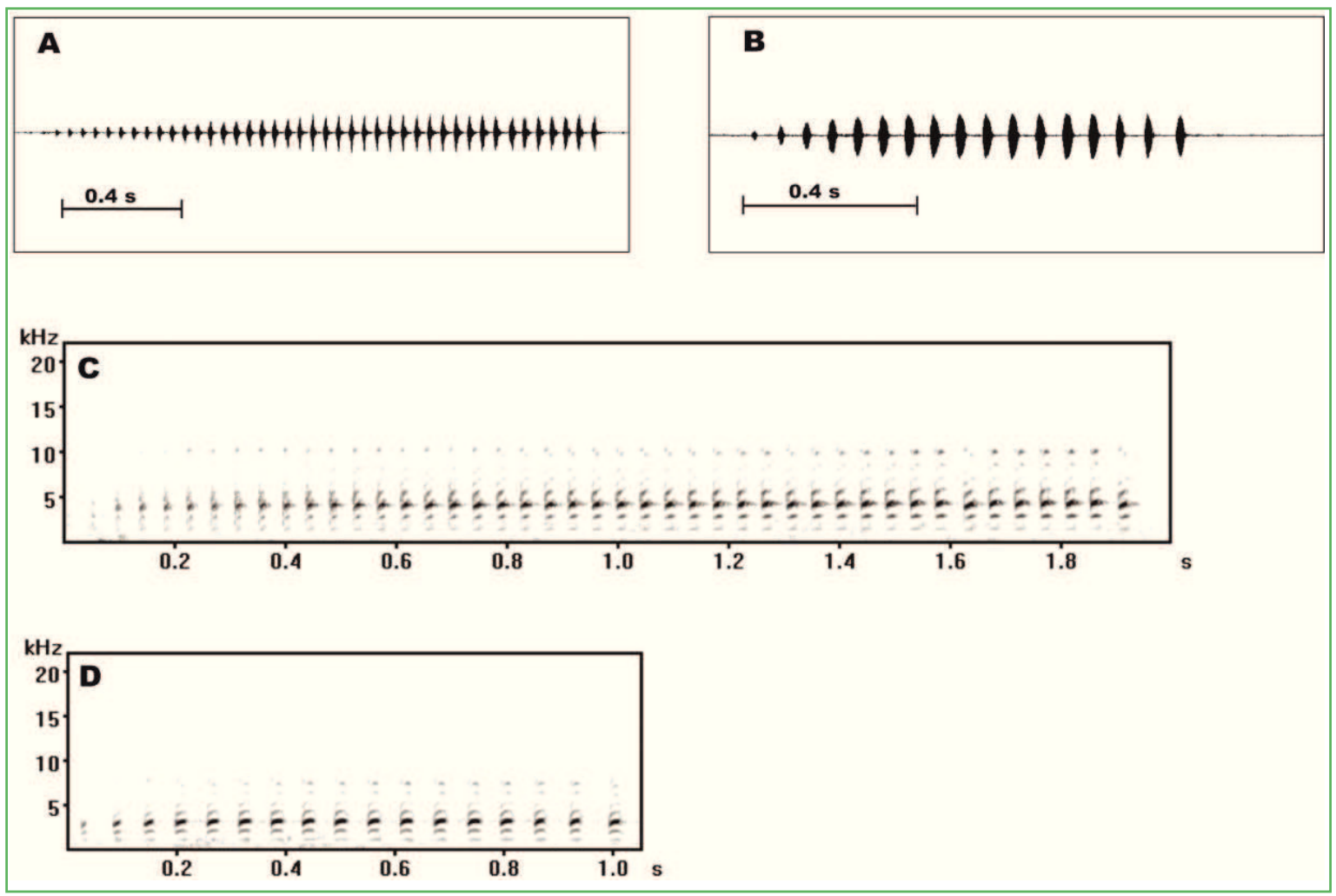


and $H$. perplicatus). Hylodes heyeri and H. perplicatus are restricted to the northern part of the state (HADDAD et al., 2003; this work), and occurrences of Hylodes in the southern part have been reported to be $H$. meridionalis (LINGNAU et al., 2013 and references therein). Surely, in the next years, new species of Hylodes in Santa Catarina will be discovered, since it is unlikely that along $1250 \mathrm{~km}$ of coastal Atlantic Forest in Santa Catarina, there are only three species of Hylodes, while in São Paulo State, a $1241 \mathrm{~km}$ extent of coastal Atlantic Forest has 10 species of this genus (ROSSA-FERES et al., 2011).

Despite an increase in taxonomic and even ecological knowledge about species of Hylodes in recent years (e.g. CANEDO; POMBAL JR., 2007; LINGNAU et al., 2008; 2013; DA SILVA; BENMAMAN, 2008), there is still not enough knowledge about the species belonging to this genus and their distribution (LAIA; ROCHA, 2012). Our findings reinforce the urgency for more field activities to enhance our knowledge of the geographic distribution of anurans, to promote their conservation, and to call attention to the importance of detailed acoustic analysis to distinguish cryptic species.

\section{Acknowledgements}

We thank Paulo C. A. Garcia and Ivan B. Amaral for their incentive to participate in the PAN Sul (RAN-ICMBIO) project and support in previous field expeditions. Ivan B. Amaral provided the photograph of $H$. perplicatus. We are grateful to Fabrício S. Meyer for his company and friendship during field expeditions. RL thanks DIRPPG/UTFPR - Campus Francisco Beltrão for financial support and $\mathrm{CNPq}$ for supporting the project 47851/2011-6. C. F. B. Haddad and L. F. Toledo kindly let us access specimens in their institutional collections. C. F. B. Haddad gave us access to his recordings of $H$. perplicatus from São Bento do Sul. We are thankful to Paula H. Valdujo for her help with ArcGis and to Univille for accommodation at CEPA Rugendas, Center for Environmental Studies and Research. We are grateful to Yara de Mello for her help with the distribution map. Two anonymous reviewers greatly improved the paper.

\section{References}

ARAÚJO, C. O.; CONDEZ, T. H.; BOVO, R. P.; CENTENO, F. C.; LUIZ, A. M. Amphibians and reptiles of the Parque Estadual Turístico do Alto Ribeira (PETAR), SP: an Atlantic Forest remnant of Southeastern Brazil. Biota Neotropica, Campinas, v. 10, p. 257274, 2010 .

CANEDO, C.; POMBAL JR., J. P. Two new species of torrent frog of the genus Hylodes (Anura, Hylodidae) with nuptial thumb tubercles. Herpetologica, Lawrence, v. 63, p. 224-235, 2007.

CONTE, C. E.; ROSSA-FERES, D. C. Diversidade e ocorrência temporal da anurofauna (Amphibia, Anura) em São José dos Pinhais, Paraná, Brasil. Revista Brasileira de Zoologia, Curitiba, v. 23, p. 162-175, 2006.

COSTA, T. R. N.; LINGNAU, R.; TOLEDO, L. F. The tadpole of the Brazilian torrent frog Hylodes heyeri (Anura; Hylodidae). Zootaxa, Auckland, v. 2222, p. 66-68, 2009.

CUNHA, A. K.; OLIVEIRA, I. S.; HARTMANN, M. T. Anurofauna da Colônia Castelhanos, na Área de Proteção Ambiental de Guaratuba, Serra do Mar paranaense, Brasil. Biotemas, Florianópolis, v. 23, n. 2, p. 123-134, 2010.

DA SILVA, H. R.; BENMAMAN, P. Uma nova espécie de Hylodes Fitzinger da Serra da Mantiqueira, Minas Gerais, Brasil (Anura: Hylodidae). Revista Brasileira de Zoologia, Curitiba, v. 25, p. 8999, 2008.

FROST, D. R. Amphibian species of the world: an online reference. Version 6.0. 2014. Accessible at: $<$ http://research.amnh. org/herpetology/amphibia/index.html $>$. American Museum of Natural History, New York, USA.

GAREY, M. V.; HARTMANN, M. T. Anuros da Reserva Natural Salto Morato, Guaraqueçaba, Paraná, Brasil. Biota Neotropica, Campinas, v. 12, p. 1-9, 2012.

HADDAD, C. F. B.; GARCIA, P. C. A.; POMBAL JR., J. P. Redescrição de Hylodes perplicatus (Miranda-Ribeiro, 1926) (Amphibia, Anura, Leptodactylidae). Arquivos do Museu Nacional, Rio de Janeiro, v. 61, n. 4, p. 245-254, 2003.

HADDAD, C. F. B.; POMBAL JR., J. P. A new species of Hylodes from southeastern Brazil (Amphibia: Leptodactylidae). Herpetologica, Lawrence, v. 51, n. 3, p. 279-286, 1995.

HADDAD, C. F. B.; POMBAL JR., J. P.; BASTOS, R. P. New species of Hylodes from the Atlantic forest of Brazil (Amphibia: Leptodactylidae). Copeia, Lawrence, v. 1996, p. 965-969, 1996.

HEYER, W. R.; RAND, A. S.; CRUZ, C. A. G.; PEIXOTO, O. L.; NELSON, C. E. Frogs of Boracéia. Arquivos de Zoologia, São Paulo, v. 31, n. 4, p. 231-410, 1990.

LAIA, R. C.; ROCHA, C. F. D. Adults and tadpoles of species of Hylodidae (Anura): History and taxonomy perspectives. Zoologia, Curitiba, v. 29, n. 1, p. 89-94, 2012.

LINGNAU, R. Geographic distribution: Hylodes heyeri. Herpetological Review, Lawrence, v. 31, p. 251, 2000.

LINGNAU, R. A importância da Área de Proteção Ambiental de Guaratuba para conservação de algumas espécies de anfíbios anuros 
no estado do Paraná, Brasil. In: CONGRESSO BRASILEIRO DE UNIDADES DE CONSERVAÇÃO, IV, 2004, Curitiba. Anais... Curitiba: WWF-Brasil, 2004. v. 1, p. 92-97.

LINGNAU, R.; BASTOS, R. P. Vocalizations of the Brazilian torrent frog Hylodes heyeri (Anura: Hylodidae): repertoire and influence of air temperature on advertisement call variation. Journal of Natural History, London, v. 41, n. 17-20, p. 12271235, 2007.

LINGNAU, R.; CANEDO, C.; POMBAL JR., J. P. A new species of Hylodes (Anura: Hylodidae) from the Brazilian Atlantic Forest. Copeia, Lawrence, v. 2008, n. 3, p. 595-602, 2008.

LINGNAU, R.; ZANK, C.; COLOMBO, P.; KWET, A. Vocalization of Hylodes meridionalis (Mertens, 1927) (Anura, Hylodidae) in Rio Grande do Sul, Brazil, with comments on nocturnal calling in the family Hylodidae. Studies on Neotropical Fauna and Environment, Tübingen, v. 48, n. 1, p. 76-80, 2013.
PAVAN, D.; NARVAES, P.; RODRIGUES, M. T. A new species of leptodactylid frog from the Atlantic Forest of southeastern Brazil with notes on the status and on speciation of the Hylodes species groups. Papéis Avulsos de Zoologia, São Paulo, v. 41, n. 23, p. 407-425. 2001

ROSSA-FERES, D. C.; SAWAYA, R. J.; FAIVOVICH, J.; GIOVANELLI, J. G. R.; BRASILEIRO, C. A.; SCHIESARI, L.; ALEXANDRINO, J.; HADDAD, C. F. B. Anfíbios do estado de São Paulo, Brasil: conhecimento atual e perspectivas. Biota Neotropica, Campinas, v. 11, Suplemento 1, p. 47-66, 2011.

TOLEDO, L. F.; LINGNAU, R. Geographic distribution: Hylodes heyeri. Herpetological Review, Lawrence, v. 33, p. 317, 2002. 